\title{
Protective effect of gigantol against hydrogen peroxide-induced apoptosis in rat bone marrow mesenchymal stem cells through the PI3K/Akt pathway
}

\author{
HUANHUAN CHEN $^{1 *}$, YUECHUN HUANG $^{2 *}$, DANDAN HUANG ${ }^{1}$, \\ ZHIFANG WU ${ }^{3}$, YUNRONG LI ${ }^{1}, \mathrm{CHUNHUA} \mathrm{ZHOU}^{1}$ and GANG WEI ${ }^{1}$ \\ ${ }^{1}$ School of Chinese Materia Medica, Guangzhou University of Chinese Medicine, Guangzhou, Guangdong 510006; \\ ${ }^{2}$ Department of Pharmacy, The First Affiliated Hospital, Guangzhou University of Chinese Medicine, \\ Guangzhou, Guangdong 510405; ${ }^{3}$ Department of Trauma Orthopedics, The Third Affiliated Hospital, \\ Guangzhou University of Chinese Medicine, Guangzhou, Guangdong 510360, P.R. China
}

Received July 5, 2017; Accepted October 24, 2017

DOI: $10.3892 / \mathrm{mmr} .2017 .8242$

\begin{abstract}
Bone marrow mesenchymal stem cell (BMSC) transplants are promising for the treatment of certain central nervous system diseases. However, oxidative stress is one of the major factors that may limit the survival of the transplanted BMSCs. The present study investigated the effect of pretreatment with gigantol on hydrogen peroxide $\left(\mathrm{H}_{2} \mathrm{O}_{2}\right)$-induced apoptosis in rat BMSCs (rBMSCs) and the potential underlying mechanisms. The results demonstrated that gigantol pretreatment significantly inhibited $\mathrm{H}_{2} \mathrm{O}_{2}$-induced apoptosis of rBMSCs. rBMSCs were incubated with $600 \mu \mathrm{M} \mathrm{H}_{2} \mathrm{O}_{2}$ in the absence or presence of different doses of gigantol (1-100 $\mu \mathrm{M})$. Cell viability and apoptosis ratios were assessed by MTT assays and flow cytometry, respectively. Morphological alterations and reactive oxygen species were measured by the fluorescent-based methods of Hoechst staining and dichlorodihydrofluorescein diacetate, respectively. Furthermore, the protein levels of phosphorylated-protein kinase B (Akt), B-cell lymphoma-2 (Bcl-2), Bcl-2-associated X (Bax), caspase-3 and caspase- 9 were investigated by western blotting. Following incubation with $\mathrm{H}_{2} \mathrm{O}_{2}$ for $2 \mathrm{~h}$, gigantol significantly inhibited
\end{abstract}

Correspondence to: Professor Gang Wei, School of Chinese Materia Medica, Guangzhou University of Chinese Medicine, 232 East Waihuan Road, Higher Education Mega Center, Guangzhou, Guangdong 510006, P.R. China

E-mail: weigang021@outlook.com

*Contributed equally

Abbreviations: rBMSCs, rat bone marrow mesenchymal stem cells; Bcl-2, B-cell lymphoma-2; Bax, Bcl-2-associated X; $\mathrm{H}_{2} \mathrm{O}_{2}$, hydrogen peroxide; PI3K, phosphatidylinositol 3-kinase; Akt, protein kinase B; ROS, reactive oxygen species

Key words: gigantol, mesenchymal stem cells, oxidative stress, apoptosis, phosphatidylinositol 3-kinase/Akt pathway the $\mathrm{H}_{2} \mathrm{O}_{2}$-induced reductions in the cell viability of rBMSCs in a dose-dependent manner. Furthermore, gigantol upregulated Akt phosphorylation and Bcl-2 expression, downregulated Bax expression, and reduced the expression of caspase- 3 and caspase- 9 in $\mathrm{H}_{2} \mathrm{O}_{2}$-treated rBMSCs, whereas an opposite effect was detected when LY294002, an inhibitor of phosphatidylinositol 3-kinase, was administered in combination with gigantol. These results indicate that gigantol may be developed as a promising neuroprotective agent for successful MSC transplantation in ischemic diseases.

\section{Introduction}

Diseases associated with cerebral ischemia are a major cause of mortality in developing countries. Ischemic stroke is associated with the acute loss of neurons, astroglia and oligodendroglia, in addition to disruption to synaptic architecture, as a result of cerebral artery occlusion (1). Certain studies have focused on the potential use of mesenchymal stem cell (MSC) transplantation in the treatment of central nervous system (CNS) diseases and injures, such as cerebral ischemia $(2,3)$. MSC therapy is considered a novel and promising strategy for the treatment of ischemic stroke, and may exert neuroprotective effects and promote the repair of neurons by secreting various neural trophic factors and replacing damaged neurons (4). However, the ischemic microenvironment negatively influences the survival rate of transplanted MSCs in injured CNS conditions due to oxidative stress $(5,6)$. Thus, improving the survival of MSCs during oxidative stress may improve the efficacy of MSC-based therapies.

Gigantol is a biphenolic compound that is primarily extracted from the stem of Dendrobium aurantiacum (7). Phenols derived from natural plants contain numerous antioxidants and therefore are typically used to study antioxidative activities (8-11). Furthermore, gigantol is reported to exhibit numerous biological functions, including anti-osmosis effects (12), antitumor effects in human liver (13) and lung (14) cancer, antimutagenic effects (15) and immunomodulatory activities (16). Additionally, gigantol 
was reported to be a potent compound for restoring sight in diabetics with cataracts (17). However, to the best of our knowledge, no previous studies have investigated the protective effect of gigantol on hydrogen peroxide $\left(\mathrm{H}_{2} \mathrm{O}_{2}\right)$-induced oxidative stress in rat bone marrow MSCs (rBMSCs). Therefore, the present study investigated whether gigantol protects against $\mathrm{H}_{2} \mathrm{O}_{2}$-induced oxidative stress in rBMSCs and whether the antioxidant mechanism of gigantol involves the phosphatidylinositol 3-kinase (PI3K)-protein kinase B (Akt) pathway.

\section{Materials and methods}

Chemicals and materials. Male 4-week-old Sprague-Dawley rats $(n=10)$ weighing 80-100 g were used in the present study and were obtained from Guangzhou Laboratory Animal Center, Guangzhou University of Chinese Medicine (Guangzhou, China). Low glucose Dulbecco's modified Eagle's medium (DMEM) and PBS were acquired from Gibco (Thermo Fisher Scientific, Inc., Waltham, MA, USA). $\mathrm{H}_{2} \mathrm{O}_{2}$ was purchased from Guangzhou Chemical Reagent Factory (Guangzhou, China). Basal medium of Sprague-Dawley rat MSCs, fetal bovine serum (FBS), glutamine, penicillin-streptomycin and trypsin were purchased from Cyagen Biosciences, Inc. (Guangzhou, China). MTT and dimethyl sulfoxide were acquired from Sigma-Aldrich (Merck KGaA, Darmstadt, Germany). Gigantol was purchased from the National Institute for Food and Drug Control (cat. no. 111875; Beijing, China). The chemical structure of gigantol is presented in Fig. 1A. Annexin V-fluorescein isothiocyanate (FITC) apoptosis, Hoechst 33258 and reactive oxygen species (ROS) assay kits were provided by Nanjing KeyGen Biotech Co., Ltd. (Nanjing, China). The PI3K/Akt inhibitor LY294002 was purchased from Selleck Chemicals (Houston, TX, USA). All other chemicals were of analytical grade.

Isolation and culture of rBMSCs. MSCs were immediately isolated from the Sprague-Dawley rats as previously described, with minor modifications (18). Briefly, Sprague-Dawley rats were sacrificed by cervical dislocation. The experimental procedures were approved by the Laboratory Animal Committee of Guangdong Province (Guangzhou, China). All treatments on animals were performed in accordance with the Guide for the Care and Use of Laboratory Animals (19). The femurs and tibias of rats were carefully cleaned of adherent soft tissue, the marrow was harvested and flushed with serum-free DMEM with $1 \%$ penicillin-streptomycin until the bone washed pale. Cells were resuspended in DMEM medium with $10 \% \mathrm{FBS}$ and $1 \%$ penicillin -streptomycin of Sprague-Dawley rBMSCs at $37^{\circ} \mathrm{C}$ with $5 \% \mathrm{CO}_{2}$ After being allowed to attach for $24 \mathrm{~h}$, hematopoietic and non-adherent cells were removed by changing the medium. Subsequently, rBMSCs were harvested for the experiments described below between the second and third passage. Cells were pretreated with gigantol for $12 \mathrm{~h}$ followed by treatment with $\mathrm{H}_{2} \mathrm{O}_{2}$ for $2 \mathrm{~h}$, both at room temperature. To determine the effect of LY294002, cells were pretreated with LY294002 (25 $\mu \mathrm{mol} / \mathrm{l})$ for $1 \mathrm{~h}$ at room temperature, followed by the treatments with gigantol and $\mathrm{H}_{2} \mathrm{O}_{2}$.
Cell viability assay. Cells were seeded in 96-well plates $\left(1 \times 10^{5}\right.$ cells $\left./ \mathrm{ml}\right)$ for $24 \mathrm{~h}$ at room temperature. To determine the effects of gigantol and $\mathrm{H}_{2} \mathrm{O}_{2}$ on rBMSC viability, cells were treated with $1,10,40,80$ and $100 \mu \mathrm{M}$ gigantol for $12 \mathrm{~h}$, or $400,500,600,700,800$ and $900 \mu \mathrm{M} \mathrm{H}_{2} \mathrm{O}_{2}$ for $2 \mathrm{~h}$, respectively. As a control, cells were treated with DMEM medium only. Furthermore, in another cell viability assay, cells were pretreated with different concentrations of gigantol $(1,10,40$, 80 and $100 \mu \mathrm{M}$ ) for $12 \mathrm{~h}$ followed by treatment with $600 \mu \mathrm{M}$ $\mathrm{H}_{2} \mathrm{O}_{2}$ for $2 \mathrm{~h}$, both at room temperature. Subsequently, $20 \mu \mathrm{l}$ MTT was added to each well and incubated at $37^{\circ} \mathrm{C}$ for $4 \mathrm{~h}$ prior to removal and addition of $100 \mu 1$ dimethyl sulfoxide. The absorbance value was measured in a microplate reader (Bio-Rad Laboratories, Inc., Hercules, CA, USA) at $490 \mathrm{~nm}$. Statistical analysis was performed on absorbance value readings.

Assessment of morphological changes. Cells were cultured in $24-w e l l$ plates $\left(5 \times 10^{5}\right.$ cells/well $)$ and treated with $80 \mu \mathrm{M}$ gigantol for $12 \mathrm{~h}$ followed by the addition of $600 \mu \mathrm{M} \mathrm{H}_{2} \mathrm{O}_{2}$ for $2 \mathrm{~h}$. Cells in the $\mathrm{H}_{2} \mathrm{O}_{2}$ group were treated with $600 \mu \mathrm{M} \mathrm{H}_{2} \mathrm{O}_{2}$ only. Cells were fixed with $4 \%$ paraformaldehyde for $10 \mathrm{~min}$ and washed with PBS twice prior to staining with Hoechst 33258 for $5 \mathrm{~min}$ at $4^{\circ} \mathrm{C}$ in the dark. Condensed nuclei and cell shrinkage were observed using an inverted and fluorescence microscope (Leica Microsystems GmbH, Wetzlar, Germany). A bright blue stain indicated apoptotic cell nuclei.

Measurement of ROS. Cells were cultured in 6-well plates $\left(1 \times 10^{6}\right.$ cells/well) and treated with $80 \mu \mathrm{M}$ gigantol for $12 \mathrm{~h}$ followed by the addition of $600 \mu \mathrm{M} \mathrm{H}_{2} \mathrm{O}_{2}$ for $2 \mathrm{~h}$, both at room temperature. Cells in the $\mathrm{H}_{2} \mathrm{O}_{2}$ group were treated with $600 \mu \mathrm{M}$ $\mathrm{H}_{2} \mathrm{O}_{2}$ only. Cells were stained with $10 \mu \mathrm{M} 2^{\prime} 7^{\prime}$-dichlorofluorescin diacetate (DCFH-DA) diluted with serum-free medium at $37^{\circ} \mathrm{C}$ for $20 \mathrm{~min}$ and later washed with serum-free medium three times. Fluorescence intensity was analyzed using a microplate reader (Bio-Rad Laboratories, Inc.) at excitation and emission wavelengths of 488 and $525 \mathrm{~nm}$, respectively. Images were captured using a fluorescence microscope (Leica Microsystems $\mathrm{GmbH}$ ). The absorbance values were obtained for statistical analysis.

Flow cytometric analysis of cell apoptosis. Cells were seeded in 6 -well plates $\left(1 \times 10^{6}\right.$ cells/well) for $24 \mathrm{~h}$ and and treated with $80 \mu \mathrm{M}$ gigantol for $12 \mathrm{~h}$ followed by the addition of $600 \mu \mathrm{M}$ $\mathrm{H}_{2} \mathrm{O}_{2}$ for $2 \mathrm{~h}$. Cells in the $\mathrm{H}_{2} \mathrm{O}_{2}$ group were treated with $600 \mu \mathrm{M}$ $\mathrm{H}_{2} \mathrm{O}_{2}$ only. Subsequently, cells were harvested and washed twice using PBS, and were resuspended in $500 \mu \mathrm{l}$ binding buffer. Annexin V-FITC stock $(5 \mu \mathrm{l})$ and propidium iodide solution $(5 \mu \mathrm{l})$ was added to the cells and incubated for $10 \mathrm{~min}$ at room temperature in the dark, and immediately analyzed using flow cytometer (BD FACSCanto II). The percentage of apoptotic cells was obtained for statistical analysis.

Protein extraction and western blot analysis. Cells were seeded in 6-well plates $\left(1 \times 10^{6}\right.$ cells/well) for $24 \mathrm{~h}$ and treated with $80 \mu \mathrm{M}$ gigantol for $12 \mathrm{~h}$ followed by the addition of $600 \mu \mathrm{M} \mathrm{H}_{2} \mathrm{O}_{2}$ for $2 \mathrm{~h}$, both at room temperature. Cells in the $\mathrm{H}_{2} \mathrm{O}_{2}$ group were treated with $600 \mu \mathrm{M} \mathrm{H} \mathrm{H}_{2} \mathrm{O}_{2}$ only. Cells in the gigantol $+\mathrm{H}_{2} \mathrm{O}_{2}+\mathrm{LY} 294002$ group were pretreated 
A<smiles>COc1cc(CCc2cc(OC)c(O)c(OC)c2)ccc1O</smiles>

C

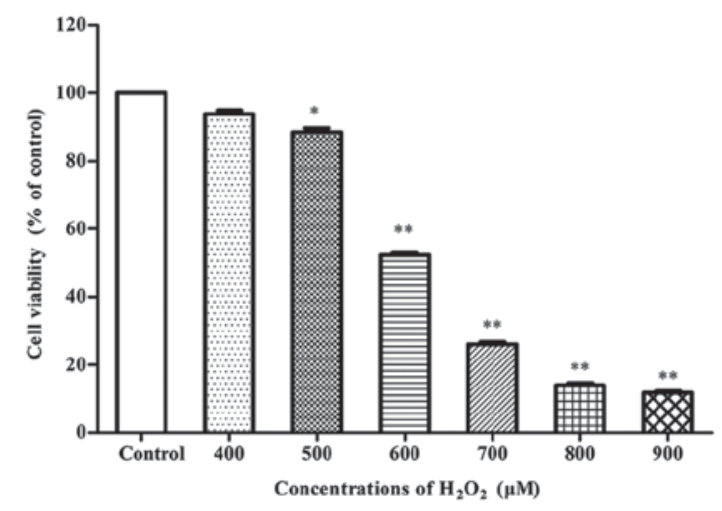

B

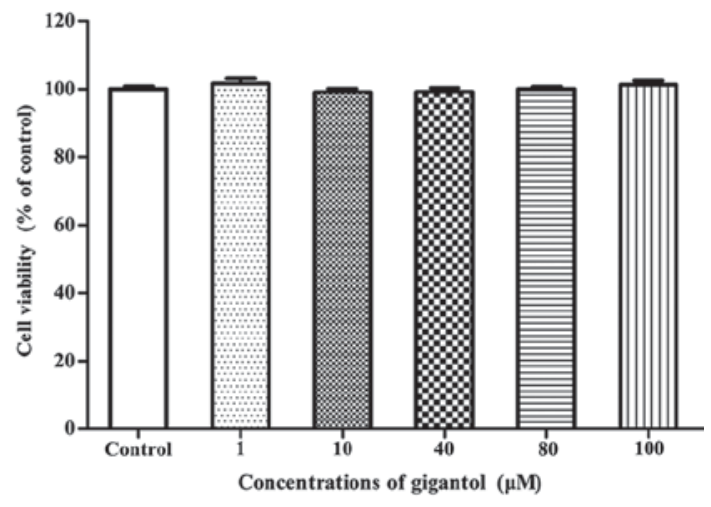

D

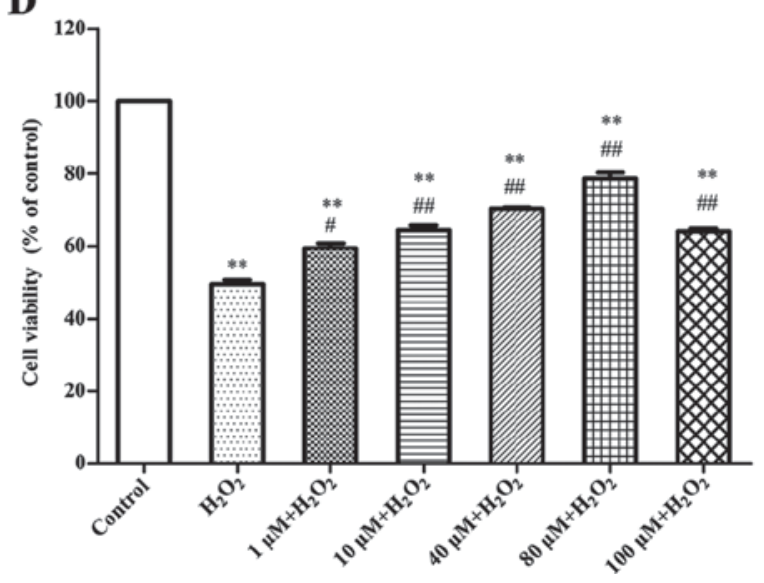

Figure 1. Effect of gigantol on the cell viability of rat bone marrow mesenchymal stem cells, as determined by MTT assays. (A) Chemical structure of gigantol. (B) Cells were cultured with various concentrations of gigantol for $12 \mathrm{~h}$. (C) Cell viability was reduced dose-dependently following treatment of cells with 400 , $500,600,700,800$ and $900 \mu \mathrm{M} \mathrm{H}_{2} \mathrm{O}_{2}$. (D) Cell viability was increased dose-dependently in cells that were pretreated with various concentrations of gigantol followed by $600 \mu \mathrm{M} \mathrm{H}_{2} \mathrm{O}_{2}$ treatment. ${ }^{*} \mathrm{P}<0.05$ and ${ }^{* *} \mathrm{P}<0.01$ vs. control group. ${ }^{*} \mathrm{P}<0.05$ and ${ }^{\# \#} \mathrm{P}<0.01$ vs. $\mathrm{H}_{2} \mathrm{O}_{2}$ only group. $\mathrm{H}_{2} \mathrm{O}_{2}$, hydrogen peroxide.

with LY294002 $(25 \mu \mathrm{mol} / \mathrm{l})$ for $1 \mathrm{~h}$ prior to gigantol with $\mathrm{H}_{2} \mathrm{O}_{2}$ treatment. Subsequently, cells were washed with PBS and lysed in cold radioimmunoprecipitation assay lysis buffer (Beyotime Institute of Biotechnology, Haimen, China) with protein inhibitor. Cellular proteins were collected and their concentrations were determined using a Bradford assay. Equal amounts of protein (40 $\mu \mathrm{g} /$ lane) were separated on $15 \%$ SDS-polyacrylamide gels and transferred onto polyvinylidene difluoride membranes via electrophoresis. After blocking with tris-buffered saline (TBS) containing 5\% skimmed milk and $0.05 \%$ Tween-20 for $1 \mathrm{~h}$ at room temperature, the membranes were incubated with the following primary antibodies: p-Akt (ser 473; cat. no. Sc7985r; 1:100; Santa Cruz Biotechnology, Inc., Dallas, TX, USA), Akt (ser 473; cat. no. Sc8312; 1:200; Santa Cruz Biotechnology, Inc.), B-cell lymphoma-2 (Bcl-2)-associated X (Bax; cat. no. 2772; 1:1,000; CST Biological Reagents Co., Ltd., Shanghai, China), Bcl-2 (cat. no. 2872; 1:1,000; CST Biological Reagents Co., Ltd.), Caspase-3 (cat. no. 9662; 1:1,000; CST Biological Reagents Co., Ltd.), Caspase-9 (cat. no. 9504; 1;1,000; CST Biological Reagents Co., Ltd.) and $\beta$-actin (cat. no. sc58673; Santa Cruz Biotechnology, Inc.) at $4^{\circ} \mathrm{C}$ overnight. After washing with TBS three times, the membranes were incubated with goat anti-rabbit immunoglobulin $\mathrm{G}$ antibodies conjugated with horseradish peroxidase (cat. no. 111-035-003; 1:1,000; Jackson Immuno Research Laboratories, Inc., West Grove, PA, USA) for $1 \mathrm{~h}$ at room temperature. Following three washes with
TBS-Tween-20, the intensity of bands was visualized using an enhanced chemiluminescence western blotting kit (Merck $\mathrm{KGaA}$ ) and quantified by densitometric analysis with ImageJ software (version 3.0; National Institutes of Health, Bethesda, MD, USA).

Statistical analysis. All experiments were conducted at least three times. Data are presented as the mean + standard error of the mean. Differences among groups were analyzed by one-way analysis of variance, followed by Dunnett's post-hoc test, using SPSS version 20 (IBM Corp., Armonk, NY, USA). $\mathrm{P}<0.05$ was considered to indicate a statistically significant difference.

\section{Results}

Gigantol inhibits $\mathrm{H}_{2} \mathrm{O}_{2}$-induced inhibition of cell viability in rBMSCs. To determine an appropriate concentration of gigantol, cells were treated with gigantol $(1,10,40,80$ and $100 \mu \mathrm{M}$ ), and the results indicated that none of these concentrations exhibited a damaging effect on cell viability (Fig. 1B). Cell viability was reduced in a dose-dependent manner when treated with 400, 500, 600, 700 and $800 \mu \mathrm{M} \mathrm{H}_{2} \mathrm{O}_{2}$ for $2 \mathrm{~h}$, compared with the control group. $\mathrm{H}_{2} \mathrm{O}_{2}$ at the concentration of $600 \mu \mathrm{M}$ significantly reduced cell viability compared with the control by $51.6 \pm 3.2 \%$ (Fig. 1C). In addition, results in Fig. 1D demonstrated that gigantol significantly increased the cell 


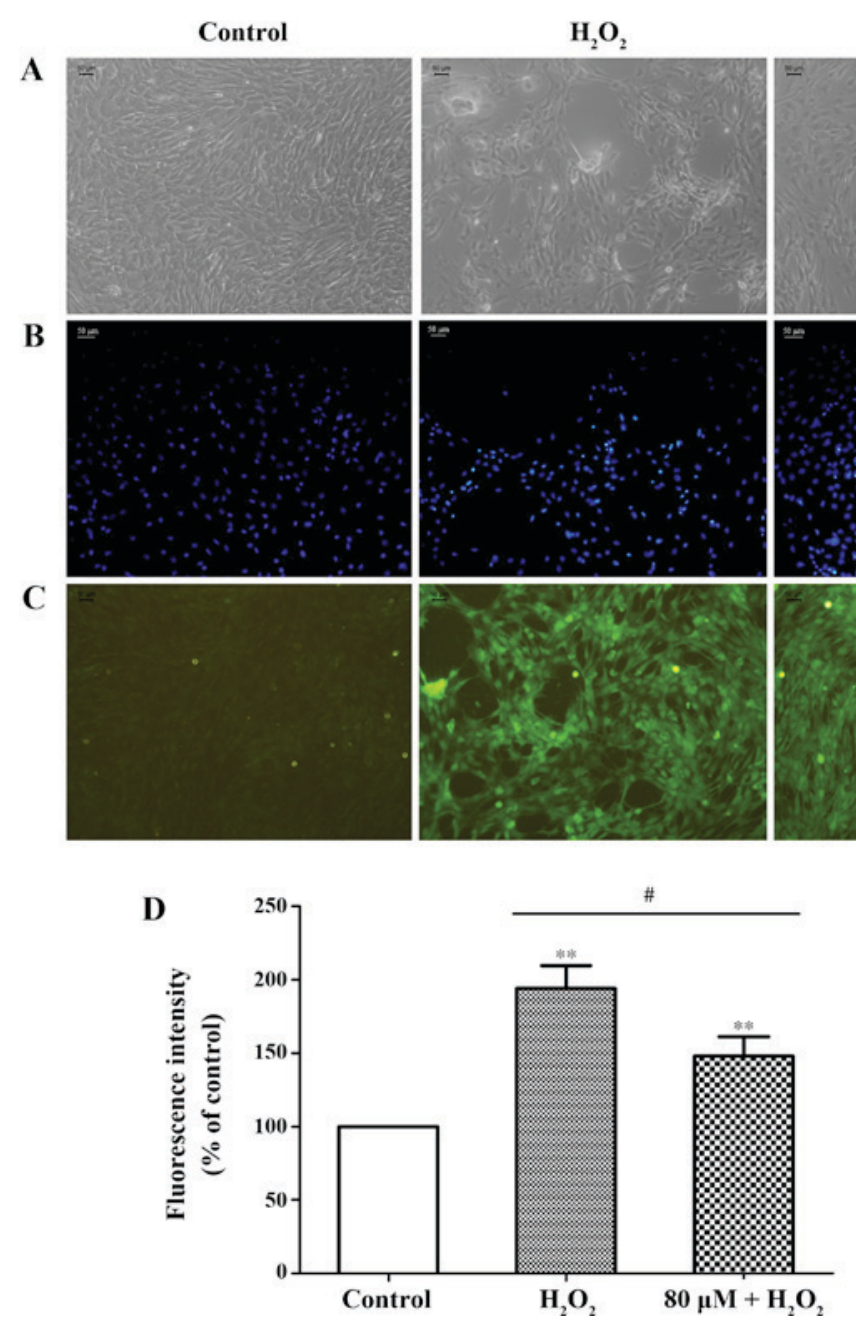

Figure 2. Effect of gigantol on apoptosis-associated morphology in rBMSCs. (A) Gigantol markedly decreased the amount of rBMSCs with apoptosis-associated morphologies induced by $\mathrm{H}_{2} \mathrm{O}_{2}$, as observed using an inverted microscope. (B) Gigantol protected rBMSCs from $\mathrm{H}_{2} \mathrm{O}_{2}$-induced morphological alterations, as observed by fluorescence microscopy using Hoechst 33258 staining. (C) Gigantol decreased the ROS levels in rBMSCs treated with $\mathrm{H}_{2} \mathrm{O}_{2}$, as determined by observing dichlorofluorescein fluorescence using fluorescence microscopy. (D) ROS levels were quantified in rBMSCs treated with $\mathrm{H}_{2} \mathrm{O}_{2}$ with or without gigantol by analyzing the fluorescence intensity with a microplate reader. Magnification, $640 \mathrm{x} .{ }^{* *} \mathrm{P}<0.01$ vs. control group. ${ }^{*} \mathrm{P}<0.05$, as indicated. rBMSCs, rat bone marrow mesenchymal stem cells; $\mathrm{H}_{2} \mathrm{O}_{2}$, hydrogen peroxide; ROS, reactive oxygen species.

viability of rBMSCs in a dose-dependent manner compared with cells treated with $\mathrm{H}_{2} \mathrm{O}_{2}$ only. Furthermore, pretreatment with $80 \mu \mathrm{M}$ gigantol significantly enhanced cell viability compared with the $\mathrm{H}_{2} \mathrm{O}_{2}$ only group (Fig. 1D). Concentrations of gigantol $>80 \mu \mathrm{M}$ reduced the stimulatory effect. Therefore, $600 \mu \mathrm{M} \mathrm{H}_{2} \mathrm{O}_{2}$ and $80 \mu \mathrm{M}$ gigantol were selected for the following experiments.

Assessment of morphological changes. Following treatment with $\mathrm{H}_{2} \mathrm{O}_{2}$, apoptosis-associated morphology was observed in rBMSCs, including detachment, irregular shape and nuclear shrinkage. However, the number of apoptosis-like cells decreased in the group pretreated with gigantol, which indicated a potential protective effect of gigantol from apoptosis induction (Fig. 2A and B).

Detection of ROS. Cellular oxidative stress was examined by a DCFH-DA assay. The results demonstrated that, in the $\mathrm{H}_{2} \mathrm{O}_{2}$-treated group, a significant increase in $2^{\prime}, 7^{\prime}$-dichlorofluorescein fluorescence was observed (Fig. 2C and D). However, pretreatment with gigantol significantly reduced the intracellular production of ROS compared with the $\mathrm{H}_{2} \mathrm{O}_{2}$-treated group (Fig. 2C and D).

Analysis of cell apoptosis. Cell apoptosis was analyzed using an Annexin $\mathrm{V}$ and propidium iodide double-staining assay by flow cytometry. The percentage of apoptotic cells in Q2 and Q4 increased from $0.5 \pm 0.45 \%$ in the control group to $49.5 \pm 3.30 \%$ in the $\mathrm{H}_{2} \mathrm{O}_{2}$ group, while apoptosis was significantly reduced to $23.4 \pm 2.06 \%$ in the gigantol $+\mathrm{H}_{2} \mathrm{O}_{2}$ group, compared with the $\mathrm{H}_{2} \mathrm{O}_{2}$ only group (Fig. 3).

Gigantol activates the PI3K/Akt pathway. The results of western blot analysis demonstrated that $\mathrm{H}_{2} \mathrm{O}_{2}$ treatment reduced the protein levels of phosphorylated (p)-Akt and the antiapoptotic protein Bcl-2 (Fig. 4A and B), and increased the levels of the proapoptotic proteins Bax, caspase-3 and caspase-9 (Fig. 4B-D). However, gigantol pretreatment lowered the caspase-3, caspase- 9 and Bax levels, and increased the levels of p-Akt and Bcl-2, compared with the $\mathrm{H}_{2} \mathrm{O}_{2}$ only group (Fig. 4). Furthermore, LY294002 (a PI3K inhibitor) significantly inhibited the protective effect of gigantol against 

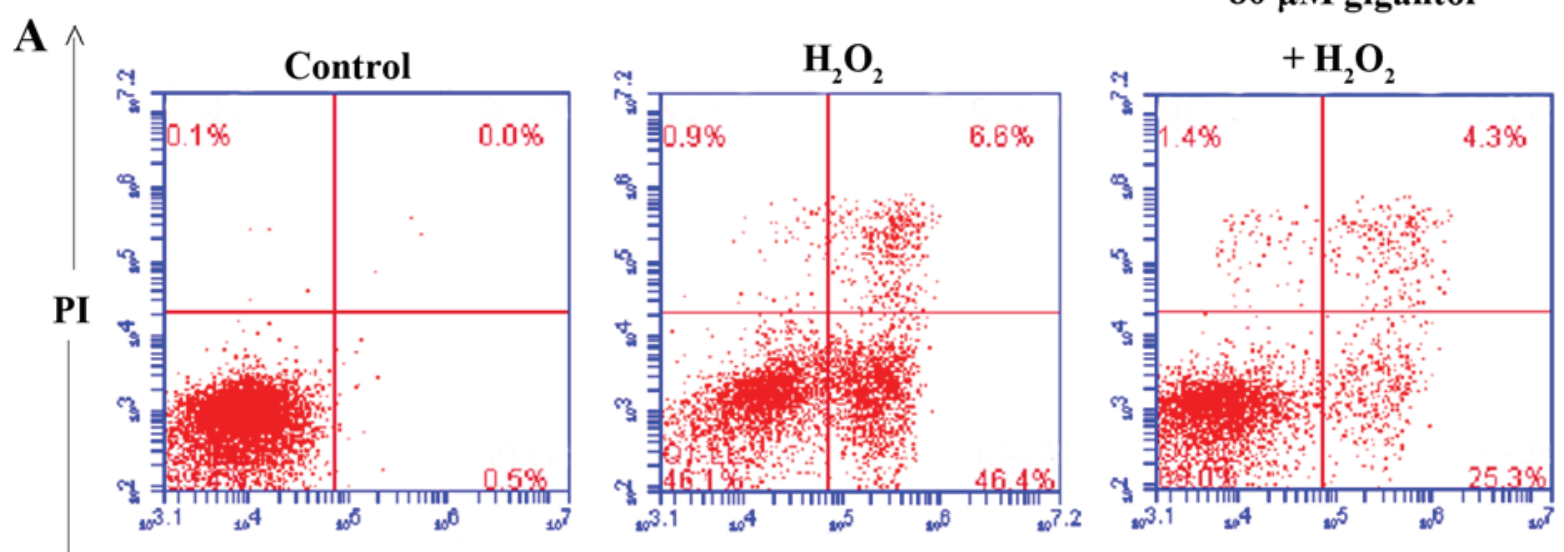

Annexin

B

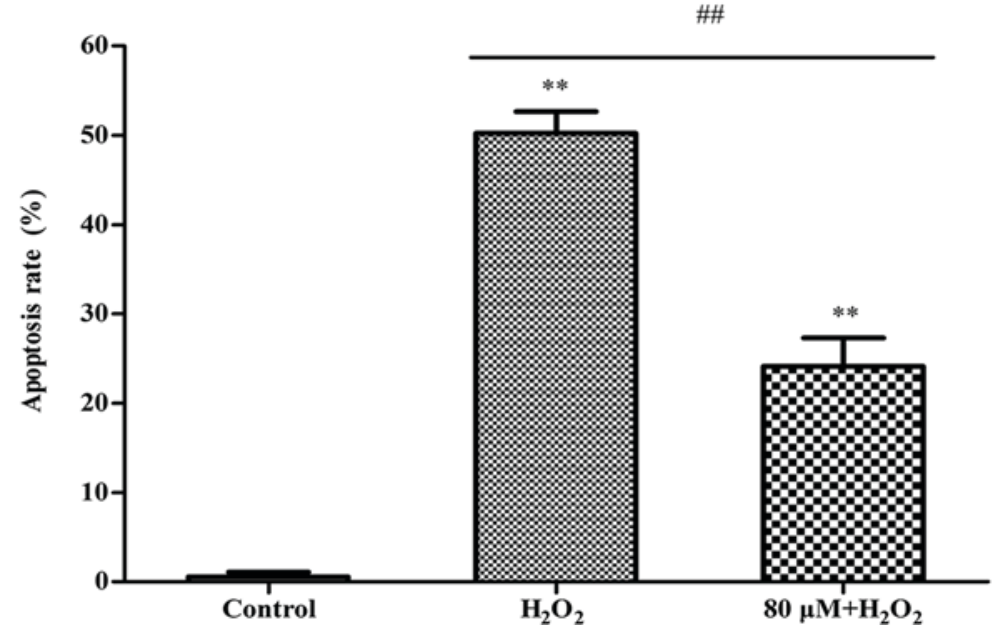

Figure 3. The effect of gigantol on rat bone marrow mesenchymal stem cell apoptosis was determined by Annexin V/PI staining. (A) Representative flow cytometry plots following Annexin V/PI staining in control, $\mathrm{H}_{2} \mathrm{O}_{2}$ and gigantol $+\mathrm{H}_{2} \mathrm{O}_{2}$ groups. (B) Apoptosis rates were statistically analyzed. The percentage of apoptotic cells in the $\mathrm{H}_{2} \mathrm{O}_{2}$ only group was $49.5 \pm 3.30 \%$, while gigantol significantly reduced the percentage to $23.4 \pm 2.06 \%$ in Q2 and Q4. ${ }^{* *} \mathrm{P}<0.01$ vs. control group. ${ }^{\# \#} \mathrm{P}<0.01$, as indicated. $\mathrm{PI}$, propidium iodide; $\mathrm{H}_{2} \mathrm{O}_{2}$, hydrogen peroxide.

$\mathrm{H}_{2} \mathrm{O}_{2}$-induced apoptosis by increasing the levels of caspase-3, caspase- 9 and the ratio of $\mathrm{Bax} / \mathrm{Bcl}-2$, and decreasing the ratio of p-Akt/Akt (Fig. 4).

\section{Discussion}

Previous studies have reported that the transplantation of human or rat MSCs led to a substantial functional improvement in stroke treatment (20-22). However, the low survival rate of MSCs that are transplanted for the treatment of an ischemic myocardium indicates that the hypoxic microenvironment may impair the survival of MSCs. $\mathrm{H}_{2} \mathrm{O}_{2}$ has successfully been used to induce oxidative stress, which led to cell apoptosis and mimicked the hypoxic microenvironment of the ischemic brain (23-25). In addition, Sun et al (26) employed a $\mathrm{H}_{2} \mathrm{O}_{2}$-induced cytotoxicity model of BMSCs to investigate damage induced by oxidative stress.

We previously reported that gigantol is abundant in Dendrobium aurantiacum among the herbal medicines grouped as Huangcao Shihu, which includes Dendrobium nobile, Dendrobium fimbriatum and Dendrobium aurantiacum (27). It is uncommon for such high concentrations of active compounds to occur naturally within plants; therefore, gigantol may be of clinical value if beneficial effects are observed. The present study, to the best of our knowledge, is the first to indicate that gigantol may have protective activities against ischemic diseases, as MTT and flow cytometry results demonstrated that gigantol inhibited $\mathrm{H}_{2} \mathrm{O}_{2}$-induced cell apoptosis in rBMSCs. Furthermore, gigantol reduced the generation of ROS in $\mathrm{H}_{2} \mathrm{O}_{2}$-treated rBMSCs, which indicates that gigantol may exhibit beneficial antiapoptotic activities through inhibition of ROS generation.

A previous report demonstrated that extracellular $\mathrm{H}_{2} \mathrm{O}_{2}$ enhanced intracellular concentrations of ROS, which subsequently inactivated p-Akt (28). In the present study, treatment of MSCs with $\mathrm{H}_{2} \mathrm{O}_{2}$ led to decreased levels of p-Akt, indicating that the PI3K/Akt signaling pathway may be inhibited in MSCs following exposure to $\mathrm{H}_{2} \mathrm{O}_{2}$. In the present study, treatment with gigantol activated the expression of p-Akt in $\mathrm{H}_{2} \mathrm{O}_{2}$-induced rBMSCs. Previous studies have demonstrated that the PI3K/Akt pathway is involved in various biological processes, including cell growth, survival and apoptosis, and also has roles in cell metabolism, proliferation and migration (29-31).

$\mathrm{PI} 3 \mathrm{~K} / \mathrm{Akt}$ is reported to prevent cell apoptosis by reducing the expression of various proapoptotic proteins, including 

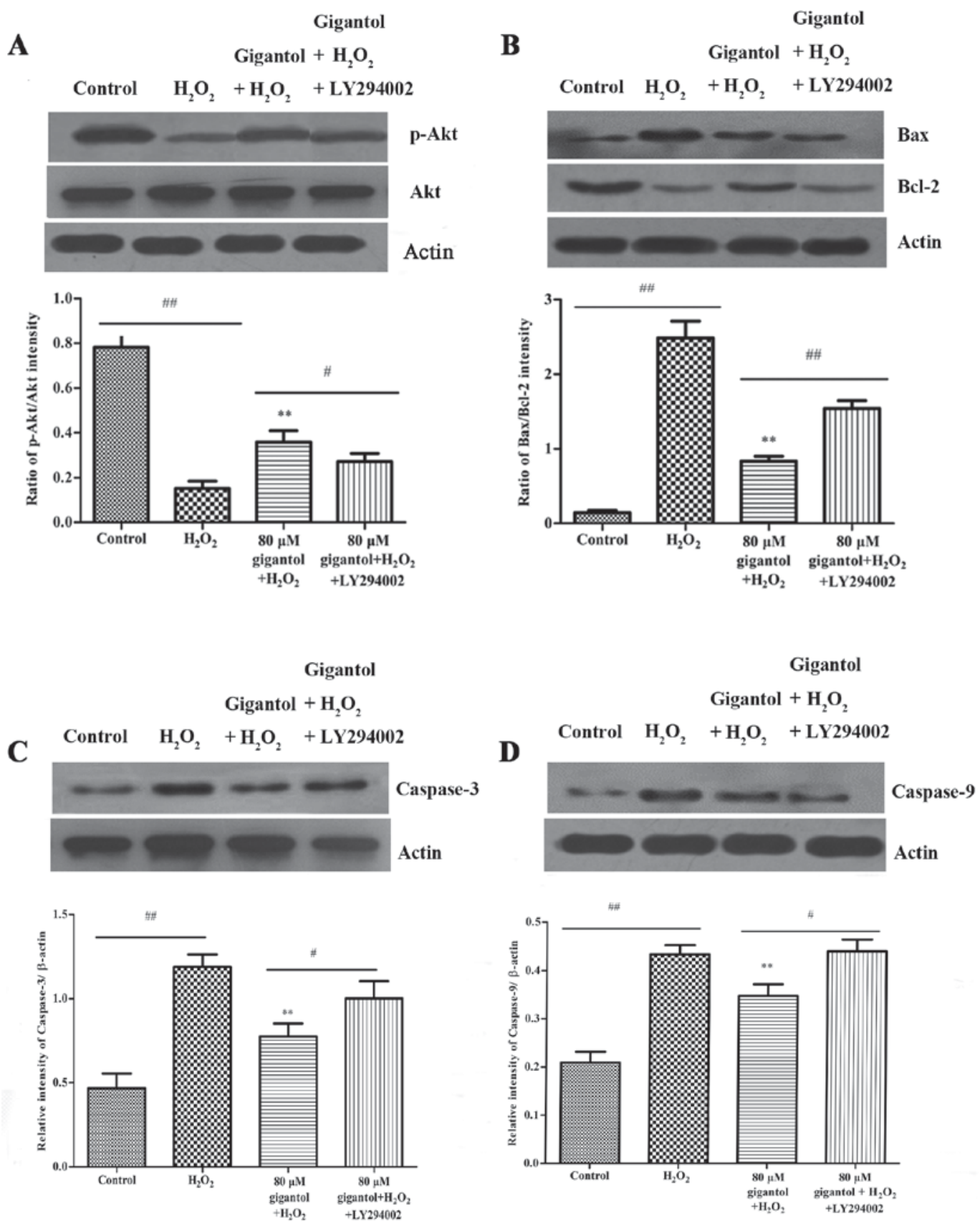

Figure 4. The effect of gigantol and LY294002 on the expression of apoptosis-associated proteins was investigated by western blot analysis. (A) Exposure of rBMSCs to $80 \mu \mathrm{M}$ gigantol significantly increased the expression of p-Akt compared with the $\mathrm{H}_{2} \mathrm{O}_{2}$ only group, while LY294002 reduced the increase in p-Akt. Akt was used as an internal control and densitometric analysis indicates the p-Akt/Akt ratio. (B) Gigantol pretreatment attenuated $\mathrm{H}_{2} \mathrm{O}_{2}$-induced upregulation of Bax and downregulation of Bcl-2, and these effects were reversed by the application of LY294002. $\beta$-actin was used as an internal control and densitometric analysis indicates the Bax/Bcl-2 ratio. (C) Gigantol inhibited the protein expression of caspase-3 in $\mathrm{H}_{2} \mathrm{O}_{2}$-induced rBMSCs and LY294002 reversed this inhibition partially. $\beta$-actin was used as an internal control. (D) Gigantol suppressed the expression of caspase- 9 in $\mathrm{H}_{2} \mathrm{O}_{2}$-induced rBMSCs, while LY294002 reversed the inhibition partially. $\beta$-actin was used as an internal control. ${ }^{* *} \mathrm{P}<0.01$ vs. $\mathrm{H}_{2} \mathrm{O}_{2}$ group; ${ }^{*} \mathrm{P}<0.05$ and ${ }^{\# \#} \mathrm{P}<0.01$, as indicated. rBMSCs, rat bone marrow mesenchymal stem cells; p-, phosphorylated-; Akt, protein kinase $\mathrm{B} ; \mathrm{H}_{2} \mathrm{O}_{2}$, hydrogen peroxide; Bcl-2, B-cell lymphoma-2; Bax, Bcl-2-associated X; actin, $\beta$-actin.

caspase-3, caspase- 9 and Bax, and by elevating the levels of the antiapoptotic protein Bcl-2 (32). These results are consistent with those of an earlier report, which indicated that PI3K-Akt signaling increased the intracellular levels of ROS and activated the proapoptotic proteins caspase-3, caspase-9 and $\mathrm{Bax}$, and inhibited the expression of $\mathrm{Bcl}-2$ (33). The results of the current study demonstrated that $\mathrm{H}_{2} \mathrm{O}_{2}$ treatment increased the $\mathrm{Bax} / \mathrm{Bcl}-2$ ratio, and caspase- 3 and caspase- 9 protein expression, in rBMSCs. However, pretreatment with gigantol suppressed the $\mathrm{Bax} / \mathrm{Bcl}-2$ ratio, and caspase- 3 and caspase-9 levels, which indicates that gigantol may protect against rBMSC apoptosis via the PI3K/Akt signaling pathway. Furthermore,LY294002, a specific PI3K/Akt inhibitor, blocked the protective effects of gigantol. These results confirmed that PI3K/Akt may be activated by gigantol to protect rBMSCs from $\mathrm{H}_{2} \mathrm{O}_{2}$-induced apoptosis.

In conclusion, the present study demonstrated that gigantol significantly inhibited $\mathrm{H}_{2} \mathrm{O}_{2}$-induced apoptosis in rBMSCs. 
The protective effect of gigantol was accompanied by reductions in intracellular ROS generation, the expression ratio of Bax/Bcl-2, and caspase- 3 and caspase-9 protein expression, in addition to increases in the ratio of p-Akt/Akt and Bcl-2 expression. Therefore, gigantol may have the potential to be developed as a protective agent for the clinical treatment of patients with ischemic diseases. Regarding the utilization of gigantol in ischemic stroke, however, further in vitro and in vivo experiments are required to investigate the effect of gigantol on transport and differentiation in rBMSCs.

\section{Acknowledgements}

The present study was financially supported by the Special Foundation of 2015 High Level University Construction (grant no. 2050205), the Special Foundation of High Level University Construction of Guang Zhou University of Chinese Medicine (grant no. A1-AFD018171Z11024) and the Science and Technology Planning Project of Guangdong Province (grant no. 2013B060400022).

\section{References}

1. Tuan RS, Boland G and Tuli R: Adult mesenchymal stem cells and cell-based tissue engineering. Arthritis Res Ther 5: 32-45, 2003.

2. De Keyser J: Autologous mesenchymal stem cell transplantation in stroke patients. Ann Neurol 58: 653-654, 2005.

3. Monsel A, Zhu YG, Gennai S, Hao Q, Liu J and Lee JW: Cell-based therapy for acute organ injury: Preclinical evidence and ongoing clinical trials using mesenchymal stem cells Anesthesiology 121: 1099-1121, 2014.

4. Hao L, Zou Z, Tian H, Zhang Y, Zhou H and Liu L: Stem cell-based therapies for ischemic stroke. Biomed Res Int 2014 468748, 2014.

5. Lee JH, Jung HK, Han YS, Yoon YM, Yun CW, Sun HY, Cho HW and Lee SH: Antioxidant effects of Cirsium setidens extract on oxidative stress in human mesenchymal stem cells. Mol Med Rep 14: 3777-3784, 2016.

6. Wei H, Li Z, Hu S, Chen X and Cong X: Apoptosis of mesenchymal stem cells induced by hydrogen peroxide concerns both endoplasmic reticulum stress and mitochondrial death pathway through regulation of caspases, p38 and JNK. J Cell Biochem 111: 967-978, 2010

7. Li Y, Wang ZT and Xu LS: Phenols and a triterpene from Dendrobium aurantiacum var. Denneanum (Orchidaceae). Biochem Syst Ecol 34: 658-660, 2006.

8. Kuppusamy S, Thavamani P, Megharaj M, Nirola R, Lee YB and Naidu R: Assessment of antioxidant activity, minerals, phenols and flavonoid contents of common plant/tree waste extracts. Ind Crop Prod 83: 630-634, 2016.

9. Wang ST, Gao W, Fan YX, Liu XG, Liu K, Du Y, Wang LL, Li HJ, Li P and Yang H: Phenol profiles and antioxidant capacities of bistort rhizoma (Polygonum bistorta L.) extracts. Rsc Adv 6: 27320-27328, 2016.

10. Temel E, Alasalvar C, Gokce H, Güder A, Albayrak C, Alpaslan YB, Alpaslan G and Dilek N: DFT calculations, spectroscopy and antioxidant activity studies on (E)-2-nitro-4-((phenylimino)methyl)phenol. Spectrochim Acta A 136: 534-546, 2015.

11. Menshchikova EB, Wisman NY, Zenkov NK, Tkachev VO and Kandalintseva NV: ARE-inducing phenol antioxidant TC-13 improves survival of drosophila melanogaster in oxidative stress. B Exp Med 154: 260-264, 2012.

12. Fang H, Hu X, Wang M, Wan W, Yang Q, Sun X, Gu Q, Gao X, Wang Z, Gu L, et al: Anti-osmotic and antioxidant activities of gigantol from Dendrobium aurantiacum var. Denneanum against cataractogenesis in galactosemic rats. J Ethnopharmacol 172: 238-246, 2015.

13. Chen H, Huang Y, Huang J, Lin LZ and Wei G: Gigantol attenuates the proliferation of human liver cancer through the PI3K/Akt/NF-אB signaling pathway. Oncol Rep 37: 865-870, 2017.
14. Bhummaphan $\mathrm{N}$ and Chanvorachote P: Gigantol suppresses cancer stem cell-like phenotypes in lung cancer cells. Evid Based Complement Alternal Med 2015: 1-10, 2015.

15. Miyazawa M, Shimamura H, Nakamura S and Kameoka H: Antimutagenic activity of gigantol from Dendrobium nobile. J Agrc Food Chem 45: 2849-2853, 1997.

16. Won JH, Kim JY, Yun KJ, Lee JH, Back NI, Chung HG, Chung SA, Jeong TS, Choi MS and Lee KT: Gigantol isolated from the whole plants of cymbidium goeringii inhibits the LPS-induced iNOS and COX-2 expression via NF- $\mathrm{B}$ inactivation in RAW 264.7 macrophages cells. Planta Med 72: 1181-1187, 2006.

17. Wu J, Lu C, Li X, Fang H, Wan W, Yang Q, Sun X, Wang M, $\mathrm{Hu}$ X, Chen CY and Wei X: Synthesis and biological evaluation of novel gigantol derivatives as potential agents in prevention of diabetic cataract. PLoS One 10: e0141092, 2015.

18. Tropel P, Noël D, Platet N, Legrand P, Benabid AL and Berger F: Isolation and characterisation of mesenchymal stem cells from adult mouse bone marrow. Exp Cell Res 295: 395-406, 2004.

19. National Research Council (US) Committee for the Update of the Guide for the Care and Use of Laboratory Animals: Guide for the Care and Use of Laboratory Animals, 8th edition. National Academies Press (US), Washington, DC, 2011.

20. Gutiérrez-Fernández M, Rodríguez-Frutos B, Ramos-Cejudo J, Teresa Vallejo-Cremades M, Fuentes B, Cerdán $S$ and Díez-Tejedor E: Effects of intravenous administration of allogenic bone marrow- and adipose tissue-derived mesenchymal stem cells on functional recovery and brain repair markers in experimental ischemic stroke. Stem Cell Res 4: 11, 2013.

21. Wei L, Fraser JL, Lu ZY, Hu X and Yu SP: Transplantation of hypoxia preconditioned bone marrow mesenchymal stem cells enhances angiogenesis and neurogenesis after cerebral ischemia in rats. Neurobiol Dis 46: 635-645, 2012.

22. Tsai LK, Wang Z, Munasinghe J, Leng Y, Leeds $P$ and Chuang DM: Mesenchymal stem cells primed with valproate and lithium robustly migrate to infarcted regions and facilitate recovery in a stroke model. Stroke 42: 2932-2939, 2011.

23. Lin YC, Huang YC, Chen SC, Liaw CC, Kuo SC, Huang LJ and Gean PW: Neuroprotective effects of ugonin K on hydrogen peroxide-induced cell death in human neuroblastoma SH-SY5Y cells. Neurochem Res 34: 923-930, 2009.

24. Zhang Q, Huang WD, Lv XY and Yang YM: Puerarin protects differentiated $\mathrm{PC} 12$ cells from $\mathrm{H}_{2} \mathrm{O}_{2}$-induced apoptosis through the PI3K/Akt signalling pathway. Cell Biol Int 36: 419-426, 2012.

25. Lee AY, Wu TT, Hwang BR, Lee J, Lee MH, Lee S and Cho EJ: The neuro-protective effect of the methanolic extract of Perilla frutescens var. Japonica and rosmarinic acid against $\mathrm{H}_{2} \mathrm{O}_{2}$-induced oxidative stress in $\mathrm{C} 6$ glial cells. Biomol Ther (Seoul) 24: 338-345, 2016.

26. Sun B, Feng M, Tian X, Lu X, Zhang Y, Ke X, Huang S, Cao J and Ding X: Dl-3-n-Butylphthalide protects rat bone marrow stem cells against hydrogen peroxide-induced cell death through antioxidation and activation of PI3K-Akt pathway. Neurosci Lett 516: 247-252, 2012.

27. Tao SC, Chen ZH, Huang KW, Yan MX and Wei G; Guangzhou University of Chinese Medicine, Foshan Hospital of Traditional Chinese Medicine Affiliated to Guangzhou University of Chinese Medicine: Comparative study of HPLC characteristic spectrum of Dendrobium fimbriatum hook and other huangcao dendrobium species. Chin Med Phar 27: 238-241, 2016.

28. Li Y, Xue F, Xu SZ, Wang XW, Tong X and Lin XJ: Lycopene protects bone marrow mesenchymal stem cells against ischemia-induced apoptosis in vitro. Eur Rev Med Pharmaco 18: 1625-1631, 2014.

29. Stambolic V and Woodgett JR: Functional distinctions of protein kinase B/Akt isoforms defined by their influence on cell migration. Trends Cell Bio 16: 461-466, 2006.

30. Osaki M, Oshimura M and Ito H: PI3KAkt pathway: Its functions and alterations in human cancer. Apoptosis 9: 667-676, 2004.

31. Song G, Ouyang G and Bao S: The activation of Akt /PIK13 signaling pathway and cell survival. J Cell Mol Med, 9: 59-71, 2005.

32. Downward J: PI 3-kinase, Akt and cell survival. Semin Cell Dev Biol 15: 177-182, 2004.

33. Kim JY, Lee JS, Han YS, Lee JH, Bae I, Yoon YM, Kwon SM and Lee SH: Pretreatment with lycopene attenuates oxidative stress-induced apoptosis in human mesenchymal stem cells. Biomol Ther 23: 517-524, 2015. 